\title{
Growth, mortality and length-weight relationship of the Bombay duck Harpadon nehereus (Ham. 1822) from North-eastern tip of the Bay of Bengal
}

\author{
ROKEYA SULTANA*, MD. ABDULLAH AL-MAMUN ${ }^{1}$, \\ ZOARDER FARUQUE AHMED ${ }^{2}$, AND MST KANIZ FATEMA ${ }^{2}$ \\ Chittagong College, Chittagong, Bangladesh \\ ${ }^{1}$ Department of Fisheries, Dhaka 1000, Bangladesh \\ ${ }^{2}$ Department of Fisheries Management, Bangladesh Agricultural University, Mymensingh 2202 \\ *E-mail: rokeya.sbi06@yahoo.com
}

\begin{abstract}
The present study was conducted to investigate the growth parameters, length-weight relationship and diverse mortality rates of Bombay duck Harpadon nehereus, from North-eastern tip of the Bay of Bengal. The length weight data were collected from January to December 2017 where a total number of 2054 individuals of both sex were analyzed. The von Bertalanffy growth parameters, the asymptotic length L $\infty$ $(\mathrm{cm})$, the growth constant $\mathrm{K}\left(\right.$ year $^{-1}$ ) and to were estimated as $38.50,0.88$, and -0.0181 years respectively. The growth performance index (Ø) was found to be 3.115. The total length and body weight (L-W) relationship was found as $\mathrm{W}=0.004 \mathrm{~L}^{3.021}$, indicating that the growth rate showed a positive allometric pattern $(b=3.021>3)$. The annual fishing morality rate $(\mathrm{F})$ was 1.89 , whereas the natural mortality rate $(\mathrm{M})$ was 1.51 . The obtained value of the exploitation rate $(\mathrm{E}=0.56)$ indicated that the said population was in over-exploited condition.

Keywords: Bombay duck, Length-Weight relationship, FiSAT
\end{abstract}

\section{Introduction}

Harpadon nehereus commonly known as Bombay duck is one of the extremely relished table fish at domestic and export markets, but few works have so far been done on it in the field of population dynamics and stock assessment (Sarker et al. 2017). It comprises more or less $10 \%$ of total catches among the all-marine fisheries production of Bangladesh. Furthermore, over the last 10 years, the annual average catch was about $61,500 \mathrm{t}$., where about $12 \%$ of this came from industrial fisheries sector and the remaining $88 \%$ was from the artisanal fisheries sector (FRSS 2017). This fish is locally called as 'Lotiya Machh' or 'Loitta' around the coastal region of Bangladesh, which is distributed in the inshore shallow water and estuarine area of the Bay of Bengal, Indian Ocean and the Arabian Sea (Sarker et al. 2017). Many authors have studied the population parameters and mortality aspects of Bombay duck of Bay of Bengal. Mustafa et al. (1998) and Khan (1989) reported that for $H$. nehereus $\mathrm{K}=0.76 /$ year, $\mathrm{L} \infty=425 \mathrm{~mm}$ along the Saurashtra coast, India. Kurian and Kurup (1992) reported $\mathrm{K}=0.52 /$ year, $\mathrm{L} \infty=426 \mathrm{~mm}$ along the Maharastra coast, India. Mustafa (2003)reported $\mathrm{L} \infty=24.48 \mathrm{~cm} \mathrm{~K}=1.50$ per year and Sarker et al. (2017) reported $\mathrm{L} \infty=45.05 \mathrm{~cm}, \mathrm{~K}=1.30$ per year in the Bay of Bengal. The present study attempts to estimate the length-weight relationship and its population dynamics like asymptotic length $(\mathrm{L} \infty)$, growth coefficient $(\mathrm{K})$, theoretical age at Zero length $\left(\mathrm{t}_{0}\right)$, total mortality $(\mathrm{Z})$, natural mortality $(\mathrm{M})$, fishing mortality $(\mathrm{F})$ and exploitation rate $(\mathrm{E})$ etc. for Bombay duck. 
ROKEYA SULTANA et al.

\section{Materials and Methods}

The samples were collected from the two landing centers: the Fishery Ghat $\left(20^{\circ} 19^{\prime} 38.33^{\prime \prime} \mathrm{N}\right.$ and $\left.91^{\circ} 50^{\prime} 50.15^{\prime \prime} \mathrm{E}\right)$ at Chattogram and the BFDC Ghat $\left(21^{\circ} 27^{\prime} 04.05^{\prime \prime} \mathrm{N}\right.$ and $\left.91^{\circ} 58^{\prime} 16.62^{\prime \prime} \mathrm{E}\right)$ at Cox's Bazar from north-eastern tip of Bay of Bengal. A total of 1731 fish specimens were randomly collected from the landing sites on monthly basis from January 2017 to December 2017. Length and weight data were measured by metric scale nearest to $\mathrm{cm}$ and $\mathrm{g}$ respectively.

The relationship between body weight and length of the fish expressed as the equation given by Le Cren (1951) as: $\mathrm{W}=\mathrm{a} \cdot \mathrm{L}^{\mathrm{b}}$. Length-Weight Relationship was established using the logtransformed equation as follows: $\log \mathrm{W}=\log \mathrm{a}+\mathrm{b} \log \mathrm{L}$, where $\mathrm{W}$ is body weight $(\mathrm{g}), \mathrm{L}$ is the total length $(\mathrm{cm})$, $a$ is the intercept and $b$ is the slope of this linear equation (Froese 2006). For ease of calculation and estimation of growth parameters and mortality of the Harpadon nehereus population, the length frequency data were grouped month wise in 2 (two) cm class interval. The data analysis were based on the Electronic Length Frequency Analysis (ELEFAN II and I) computer program that was incorporated in the FAO-ICLARM stock assessment tools (FiSAT; Gayalino et al. 1994). "K Scan" option of the FiSAT II was used to estimate these parameters according to Gayanilo et al. (2005) recommendation.

The growth equation conventionally used in fisheries science the von Bertalanffy growth equation and in the notation of Beverton and Holt (1956)equation, which is expressed as $\mathrm{L}_{t}=\mathrm{L}_{\infty}$ $\left[1-\exp ^{-k}{ }^{(t-10)}\right]$, where, $L_{t}$ is the length at age $t, L_{\infty}$ is asymptotic length, $k$ is the growth coefficient, and to is the theoretical age of fish at zero length, which was estimated from the 'Analysis of Length-at-Age data' routine of FiSAT II software. The growth performance index (Ø)for Harpadon nehereus population was calculated based on the equation given by Pauly and Munro (1984), is as follows: $\varnothing^{\prime}=\log \mathrm{K}+2 \log \mathrm{L}_{\infty}$. Here, $\mathrm{k}$ and $\mathrm{L} \infty$ were used from von Bertalanffy growth parameters. The total mortality rate $\mathrm{Z}$ (instantaneous mortality) was estimated by length converted catch curve produced by the ELEFAN II routine (Pauly 1983, Saeger and Gayanilo 1986) and natural mortality rate (M) was estimated using the following empirical equation proposed by Pauly and Gaschut (1980), i.e. $\log M=-0.0066-0.279 \log \mathrm{L}_{\infty}$ $+0.6543 \log \mathrm{K}+0.4634 \log \mathrm{T}$, where, $\mathrm{L}_{\infty}$ is the asymptotic length expressed in $\mathrm{cm}, \mathrm{T}$ is the mean annual habitat temperature expressed in ${ }^{\circ} \mathrm{C}$, which is taken $27^{\circ} \mathrm{C}$. Annual fishing mortality was estimated by subtracting of $\mathrm{M}$ from $\mathrm{Z}$. Estimation of exploitation rate $\mathrm{E}$ was calculated by the Gulland's (1971) equation of $\mathrm{E}=\mathrm{F} / \mathrm{Z}=\mathrm{F} /(\mathrm{F}+\mathrm{M})$. The age at zero length (to) was estimated from Pauly (1979) empirical equation, $\log \left(-\mathrm{t}_{0}\right)=-0.392-0.275 \log \mathrm{L}_{\infty}-1.038 \mathrm{~K}$.

\section{Results and Discussion}

Growth: The growth curve computed from the "K Scan" option of the FiSAT II over its restructured length distribution is shown in Fig. 1. The estimated value of to, $\mathrm{L} \infty$ and $\mathrm{K}$ was as $0.0181,38.50 \mathrm{~cm}$ and $0.88 /$ year respectively. Ghosh et al. (2009) reported the $\mathrm{L} \infty=35.39 \mathrm{~cm}$ and $\mathrm{K}=0.86 /$ year from the Saurashtra coast of India which is very close to the present study $38.50 \mathrm{~cm}$ and $0.88 /$ year gradually. Sarker et al. (2017) reported the $L \infty=45.05 \mathrm{~cm}$ and $\mathrm{K}=1.30 /$ year from the Bay of Bengal where Mustafa et al.(1998) reported $\infty \infty=24.48 \mathrm{~cm}$ and $\mathrm{K}=1.50 /$ year and Mustafa et al. (1994) reported $\mathrm{L} \infty=29.00 \mathrm{~cm}$ and $\mathrm{K}=0.9 /$ year for $H$. nehereus from the Kumira estuary and Islam (1995)also reported that $\mathrm{L}=30.00 \mathrm{~cm}$ of the species in the Karnafully estuary of Bangladesh. Khan (1989) reported that for $H$. nehereus $\mathrm{K}=$ 
0.7618, $\mathrm{L} \infty=425 \mathrm{~mm}$ along the Saurashtra coast, India. Kurian and Kurup (1992) reported that $=0.52 /$ year, $L \infty=426 \mathrm{~mm}$ along the Maharashtra coast, India. Calculated growth performance index (Ø) was found to be 3.12, where Sarker et al. (2017) reported $\varnothing^{\prime}=3.42$.

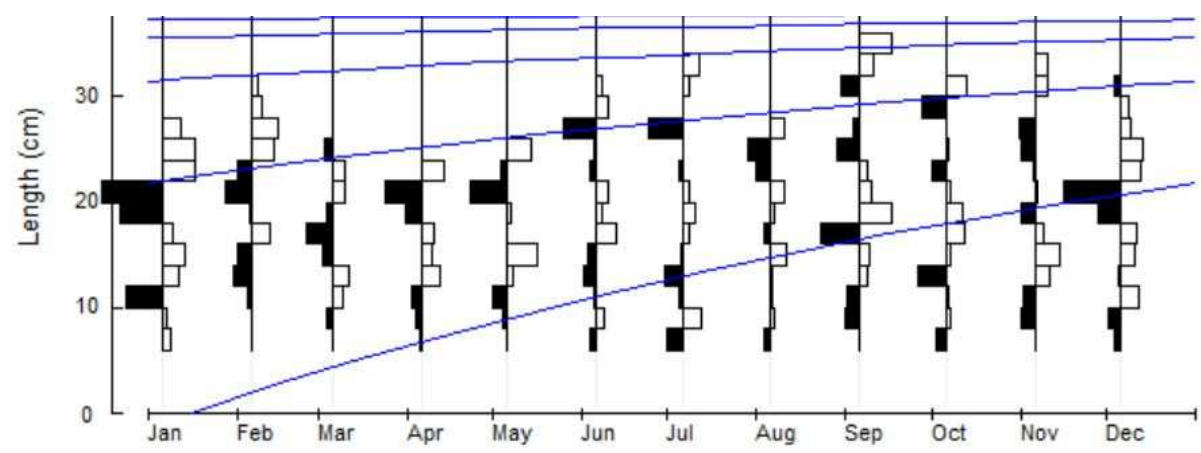

Fig. 1. Restructured growth curve of H. nehereus.

Mortality and exploitation rate: The mortality rates $\mathrm{M}, \mathrm{F}$ and $\mathrm{Z}$ computed were $1.51,1.89$ and 3.40,respectively. Fig. 2 represents the catch curve utilized in the estimation of $Z$. The dark circles represent the points used in calculating $\mathrm{Z}$ through least squarelinear regression. The blank circles represent points either not fully recruited or nearing to $L \infty$ hence discarded from calculation. Good fit to the descending right hand limits of the catch curve was considered. Ghosh et al. (2009) computed the M, F and Z from the Saurashtra coast of India as 1.52, 1.73 and 3.25 respectively, which is very similar to the present study. Sarker et al. (2017) estimated $\mathrm{M}, \mathrm{F}$ and $\mathrm{Z}$ as 1.86, 2.58 and 4.44 respectively from the Bay of Bengal where Mustafa et al. (1994) computed M, F and Z were 2.46, 3.27 and 5.73, respectively from Kumira, Chittagong inthe Bay of Bengal. Balli et al. (2011) estimated M, F and Z were 1.30, 3.03 and4.33, respectively from Mumbai waters, India. Khan (1989) estimated Z, M and F2.784, 1.572 and 1.212 , respectively along the Saurashtra coast, India.

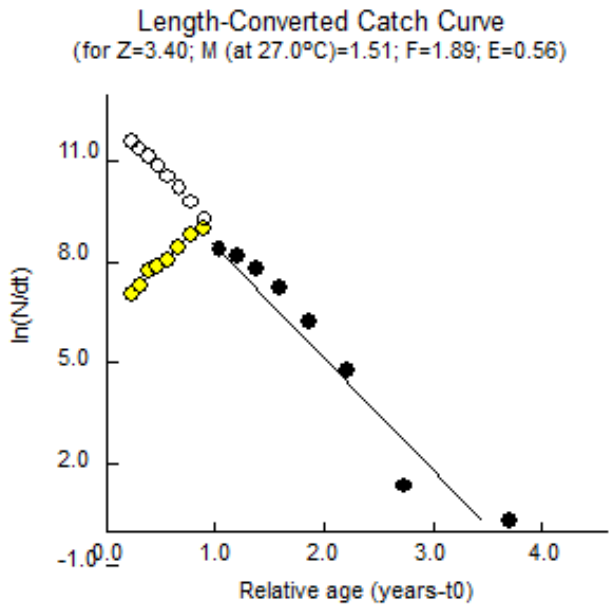

Fig. 2. Length converted catch curve of $H$. nehereus. 
The exploitation rate (E) was estimated from the Gulland's (1971) equation, $\mathrm{E}=\mathrm{F} / \mathrm{F}+\mathrm{M}$. From these range of values of $\mathrm{F}$ and $\mathrm{Z}$ it can be shown that the rate of exploitation (E) is 0.56 . It indicated that the northern part of the Bay of Bengal population of H. nehereus was in overexploited condition. This assumption is based on Gulland (1971) who stated that suitable yield is optimized when $\mathrm{F}=\mathrm{M}$ and when $\mathrm{E}$ is more than 0.5 , the stock is generally supposed to be over fished. Mustafa et al. (1994), Islam (1995), Mustafa et al. (1998) and Sarker et al. (2017) also reported the over exploitation of the species in the coastal region of Bangladesh. Ghosh et al. (2009) observed the exploitation rate 0.53 in the Saurashtra coast of India.

Present study observed the total length and weight data value ranged from 7 to $39 \mathrm{~cm}$ and 0.3 to $320 \mathrm{~g}$, respectively. From the regression analysis of L-W relationship of $H$. nehereus it was found as $\mathrm{W}=0.004 \mathrm{~L}^{3.021}$ (Fig.3), indicating that the growth rate showed positive allometric pattern $(b=3.021>3)$ with $\mathrm{r}^{2}=0.888$. From the Bay of Bengal coast, Mustafa et al.(1998) estimated the negative allometric and Sarker et al. (2017) reported $b=3.00$.

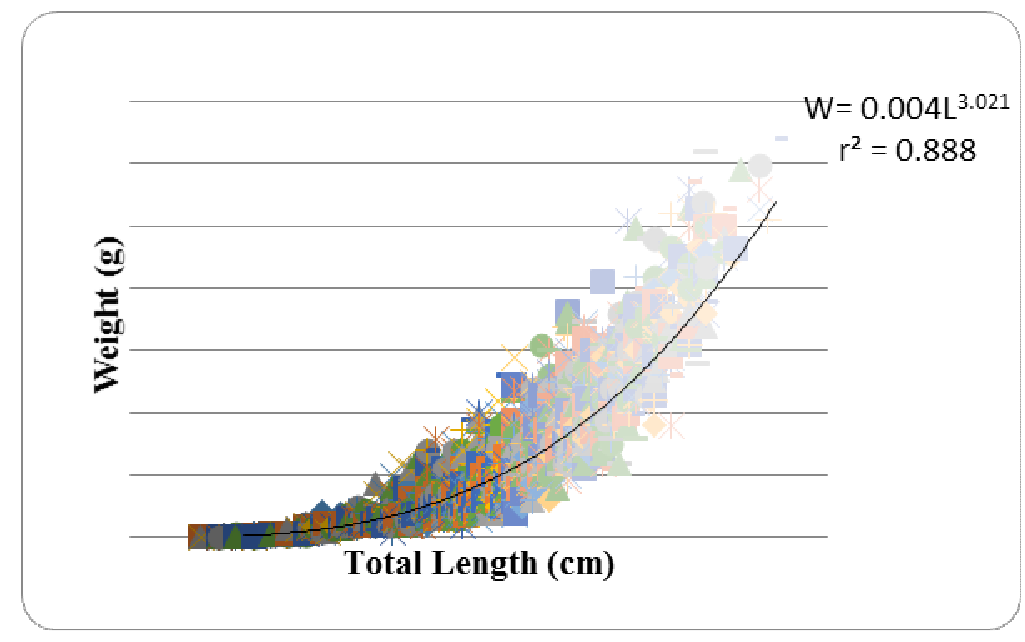

Fig. 3. The total length $(\mathrm{cm})$ and body weight $(\mathrm{g})$ relationship of $H$. nehereus

The current study revealed that, said population is under over exploitation in the Bay of Bengal, Bangladesh contexts. As most of the recent studies including present one also have estimated the over exploitation condition of $H$. nehereus in this region so, this findings will help to formulate the management strategies and conservation policies of this species and would be helpful for further development of this species in the eastern part of the Bay of Bengal, Bangladesh.

\section{Literature Cited}

Balli, J.J., S.K. Chakraborty and A.K. Jaiswar, 2011. Population dynamics of Bombay duck Harpadontidae nehereus (Ham. 1822) (Teleostomi/Harpadontidae) from Mumbai waters. Indian J. Geo-Marine Sci., 40(1): 67-70. 
GROWTH, MORTALITY AND LENGTH-WEIGHT RELATIONSHIP OF THE BOMBAY DUCK

Beverton, R.J.H. and S.J. Holt, 1956.A review of method for estimating mortality rates in fish population, with special references to sources of bias in catch sampling. Rapp. P-V. Reen. Cons. Inst. Explor. Mer., 140: 67-83.

Froese R., 2006. Cube law, condition factor and weight-length relationships: History, meta-analysis and recommendations. J. Ichthyol., 22: 241-253.

FRSS, (Fisheries Resources Survey System), 2017. Fisheries Statistical Report of Bangladesh, Department of Fisheries, Bangladesh.

Gayanilo, F.C., P. Sparre and D. Pauly, 2005. FAO-ICLARM Stock Assessment Tools II (FiSATII), User's Guide, Computerized Information Series (Fisheries) No. 8, (Revised Version), Food and Agriculture Organization of the United Nations, Rome, Italy.

Gayanilo, F.C.Jr., P. Sparre, D. Pauly, 1994.The FAO-ICLARM stock assessment tools (FiSAT) user's guide. FAO Comp. Info. Ser. (Fisheries) 6. 186 p.

Ghosh, S., N.G.K. Pillai and H.K. Dhokia, 2009.Fishery and population dynamics of Harpadon nehereus (Ham.) off the Saurashtra coast, Indian J. Fish., 56(1) : 13-19.

Gulland, J.A., 1971.the fish resources of the Oceans, West by fleet, Survey, Fishing News (books), for FAO 255.

Islam, S.S., 1995. Population dynamics of some fishes and shrimp of Karnafully river estuary basedon length-frequency data. M.Sc. Thesis, Department of Zoology, University of Chittagong, Bangladesh. 37-76.

Khan, M.Z., 1989. Population dynamics of Bombay duck, Harpadon nehereus (HAM.), of Saurashtra coast. Indian J. Fish., 36(2): 93 -101.

Kurian, A. and N. Kurup, 1992. Stock assessment of Bombay duck H. nehereus (Hamilton) of Maharastra coast. Indian J. Fish., 39(3\&4).

Le Cren, E.D., 1951.the length-weight relationship and seasonal cycle in gonad weight and condition in the perch (Perca fluviatilis). J.f Animal Ecology, 20: 201-219.

Mustafa, M.G,. 2003. Trophic model of the coastal ecosystem in the waters of Bangladesh, Bay of Bengal. World Fish Center Conference Proceedings. 67: 263-280.

Mustafa, M.G., M. Zafar, A.K.M.A. Matin and S.M.N. Amin, 1998. Population dynamics of Harpadon nehereus (Hamilton- Buchannan.) from the Kutubdia channel of Bangladesh. Bangladesh J. Fish. Res. 2(1): 83-90.

Mustafa, M.G., M.A. Azadi and M.S. Islam, 1994. ELEFAN based population dynamics of Bombay duck Harpadon nehereus Hamilton-Buchman from the Kumira estuary. Paper presented 9th National Zool. Conf. of the Zoological Society of Bangladesh. 26-28 January,1994.

Pauly, D. and J.L Munro, 1984. Once more growth comparisons in fish and invertebrates. Fish Byte 2: 21.

Pauly, D. and Z. Gaschut, 1979. A simple method for fitting oscillating length growth data, with a program for pocket calculators. International Council for the Exploration of the Sea, C.M. 1979/G:24, $26 \mathrm{p}$.

Pauly, D., 1980. On the interrelationship between natural mortality, growth parameters and mean environmental temperature in 175 fish stocks. J. CIEM 39: 175-192.

Pauly, D., 1983. Some simple methods for the assessment of tropical fish stocks. FAO. Fish. Tech. Pap. 235: $52 \mathrm{p}$.

Saeger, J. and F.C.Jr. Gayalino, 1986. A revised graphics oriented version of ELEFAN 0, I and II basic programs for use on HP 86/87 microcomputers. Tech. Rep. Dept. Mar. Fish. Tech. Rep. 8: 233 p.

Sarker, M.N., M. Humayun, M.A. Rahman and M.S. Uddin, 2017.population dynamics of Bombay duck Harpadon nehereus of the Bay of Bengal along Bangladesh coast Bangladesh J. Zool. 45(2): 101-110.

(Manuscript received 29 February 2020) 